\section{Full circle}

To the Editor: At a junior school reunion in Port Elizabeth a few years ago I renewed friendship with Philip Bateman, whom I so clearly remembered from my first evening as a boarder in 1956, far away from home. He had held out something edible and said: 'Quis?'

'Ego!' had yelled everyone but me. I learnt Latin fast after that.

I visited Cape Town, and Philip invited me home for dinner. There I met his wife Caroline, and her father, Edward Gale. Edward and I discovered a synchronicity when he learnt that I was a flying doctor of sorts, and that one of my regular visits was to the Church of Scotland Hospital at Tugela Ferry - COSH in modern parlance.

A Church of Scotland mission station had been established for many years near Pomeroy, Natal, when its new medical facility was moved to nearby Tugela Ferry for better water supply. In the early 1930s, COSH was established on an undeveloped site by Dr George William Gale, who was born in Durban but had studied medicine on a scholarship in Edinburgh. He was a pioneer of primary healthcare, and in time became Secretary for Health in the Smuts government. He was also instrumental in the establishment of the medical school at the University of Natal in Durban, and became its first dean in 1952. He died in 1976 after a most distinguished career, both in South Africa and internationally.

His son Edward remembers COSH with great fondness, as he lived there from the age of three. His four years at the mission hospital determined his choice of profession, and he returned there to work and learn during vacations as a Wits medical student. He has taken his own family back to visit the dramatic aloe-clad valley where it is situated. One such visit was for the memorial service for George Gale. There could have been no more fitting place in which to remember this extraordinary man than the chapel there, on a hot African afternoon, with Zulu song ringing out: the place where he had worked and cared with such fervour.
From small beginnings $\mathrm{COSH}$ has become a remarkable hospital in a remote and impoverished part of KwaZulu-Natal. Of course it is famous, not merely notorious, for the discovery, characterisation and management of extensively drug-resistant tuberculosis in 2005, and it has consequently become an important facility for research into HIV-AIDS and TB, in association with Yale University. Until recently, when Theo van der Merwe moved to Mossel Bay, he, Tony Moll and Francois Eksteen were a trio of doctors with combined continuous service of almost 70 years. $\mathrm{COSH}$ attracts young doctors and medical students, and enjoys a heyday similar to that of Charles Johnson Memorial Hospital, Nqutu, when Anthony and Maggie Barker ran it as a mission hospital in the 1960s and 1970s.

Dr Edward Gale is a cardiologist, and retired from his Johannesburg practice not that long ago. He wondered whether his still modern and functional ECG machine would be of value to COSH. The transfer by air of a largeish heavy suitcase from Cape Town to Durban was organised by the Red Cross Air Mercy Service (AMS), which is the transport arm of the outreach programme in KZN. Mr Meshach Nehemiah, who drives the Pietermaritzburg AMS vehicle, picked it up. His next trip to $\mathrm{COSH}$ coincided with my regular second-Tuesday-ofthe-month visit.

Dr Gale Junior's ECG machine arrived safely and appropriately at $\mathrm{COSH}$ on 11 November 2014, to an enthusiastic reception at the eight oclock morning meeting - with the photograph below to prove it.

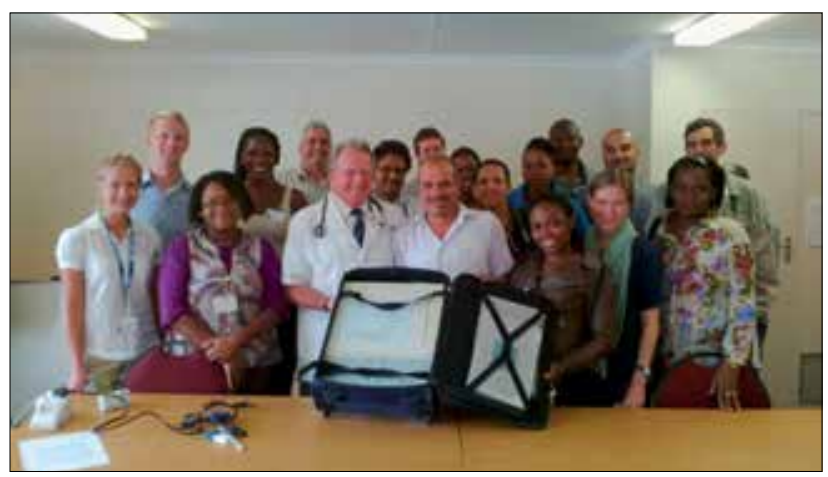

Medical staff, Church of Scotland Hospital.

\section{Robert-Ian Caldwell}

Sessional Physician for Internal Medicine Outreach, Grey's Hospital, Pietermaritzburg, South Africa robertcaldwell@telkomsa.net

S Afr Med J 2015;105(2):81. DOI:10.7196/SAMJ.9250 